\title{
IMPACT OF INFLUENCER MARKETING ON CONSUMER BEHAVIOR
}

\author{
[Vplyv influencer marketingu na spotrebitel'ské správanie] \\ Petra Gundová ${ }^{1}$, Katarína Cvoligová ${ }^{2}$ \\ ${ }^{1}$ Univerzita Mateja Bela v Banskej Bystrici, Ekonomická fakulta, Tajovského 10, 97590 Banská Bystrica \\ Email: petra.gundova@umb.sk \\ ${ }^{2}$ Univerzita Mateja Bela v Banskej Bystrici, Ekonomická fakulta, Tajovského 10, 97590 Banská Bystrica
}

\begin{abstract}
Current trends in marketing communication present influencer marketing as a new tactic in marketing strategy solutions. The article is focused on the impact of influencer marketing on consumer behavior. The aim of the article is to find out, based on questionnaire survey's results, whether selected segment of consumers considers influencer marketing to be important factors affecting their consumer behavior. Given the results of a questionnaire survey conducted by ourselves, a group of women who follow the influencers was defined for the Y generations, i. e. age range from 19 to 25 years. The basic feature of this generation is technical prowess, so the results corresponds to the interest of respondents.
\end{abstract}

Keywords: consumer behaviour, influencer, influencer marketing, social media.

JEL classification: M30, M31

Received: 7.6.2019; Reviewed: 16.7.2019; 14.9.2019; Accepted: 30.10.2019

\section{Úvod}

Hlavnou črtou súčasnosti je neustála zmena, na čo reagujú aj marketingoví manažéri podnikov. Aktivita spotrebitel'ov na sociálnych siet'ach, ktorá je prirodzená a nenútená, je to, čo prinútilo marketingových odborníkov uskutočnit’ radikálne zmeny v oblasti marketingovej komunikácie. Zmena spotrebitel'ského správania vedie prirodzene k zmene v spôsobe propagácie a prezentácie produktov. Práve influenceri predstavujú nenútený a môžeme povedat', že stále inovatívny spôsob akým možno produkty pre zákazníkov zviditel'nit', pričom v tomto prípade dochádza k cielenému osloveniu zákazníkov (Lee, Hong 2016). Podniky si začínajú uvedomovat', že ak chcú byt' v súčasnom konkurenčnom prostredí úspešné, sú pre nich inovatívnost', flexibilita a kreativita dôležité v každej oblasti (Minárová 2017), pričom marketingová komunikácia a stratégia nie sú výnimkou. Z pohl'adu podniku je výber správnej marketingovej stratégie pomerne kl'účová záležitost', pričom práve influencer marketing môže byt' vel'mi sofistikovaný tak z pohl'adu času, financií, formy a efektívnosti (Lee, Watking 2016). Dokonale zapadá do dnešnej spoločnosti, kedy byt' online je „in“.

Ciel'om predloženého príspevku je na základe dotazníkového prieskumu zistit', či vybraný segment spotrebitel'ov považuje influencerov za dôležitý faktor, ktorý ovplyvňuje spotrebitel'ské správanie. Hlavný ciel' sme sa rozhodli rozdelit' do dvoch čiastkových ciel'ov. Prvým čiastkovým ciel'om je zistit' hlavné dôvody, prečo respondentky sledujú influencerov. Druhým čiastkovým ciel'om je zistit', či influencer marketing má vplyv na spotrebitel'ské správanie respondentiek a či si na základe odporúčania influencera zakúpili v minulosti určitý produkt. Výberový súbor predstavuje segment žien. Na vyššie uvedené čiastkové ciele nadväzujú dva predpoklady, ktorých pravdivost' bude overovaná na základe výsledkov dotazníkového prieskumu. Príspevok je členený do dvoch hlavných kapitol. V prvej kapitole prezentujeme teoretické východiská influencer marketingu a jeho nástroje v nadväznosti na 
trendy v marketingovej komunikácii v 21. storočí. V úvode druhej kapitoly je priblížená metodika výskumu, pričom klúčovou čast'ou je prezentovanie výsledkov realizovaného dotazníkového prieskumu. V závere predloženého príspevku overujeme stanovené predpoklady a následne prezentujeme najdôležitejšie zistenia, ako aj isté odporúčania.

\section{Teoretické vymedzenie influencer marketingu}

Influencer marketing môžeme považovat' za jeden $\mathrm{z}$ najvplyvnejších trendov súčasnej marketingovej komunikácie (Lagree a kol. 2019). Autorky Přikrylová a Jahodová (2010) ho definujú ako identifikovanie a ovplyvňovanie názorových vodcov, u ktorých je pravdepodobnost', že budú hovorit' o produkte a majú schopnost' ovplyvnit' názory ostatných spotrebitel'ov. Môžeme sa stretnút' s tým, že pomenovanie influencerov závisí aj od nástroja, ktorý influenceri používajú na svoju prezentáciu napr. „youtuberi“, „,instagrammeri“, „bloggeri“ (Hastings 2007; Kádeková, Holienčinová 2018). Niektorí influenceri nie sú spokojní s pomenovaním, ktoré je spojené skôr s užívatel’om istej sociálnej siete ako s nejakou profesiou. To bolo dôvodom, prečo názov svojej práce povýšili na „creators“ (angl. creators - tvorca, tvorivý človek).

Mohli by sme tvrdit', že influencer marketing je forma internetového marketingu, ktorá sa zameriava predovšetkým na jedincov, ktorí disponujú určitým potenciálom ovplyvnit' správanie vel'kej ciel'ovej skupiny (Bokunewitz, Shulman 2017). Daný influencer môže pre zákazníkov predstavovat' symbol významnej referencie. Influenceri sú často (nie vždy) širokej verejnosti známi l'udia, ktorí pre čast' spoločnosti predstavujú inšpiráciu, autoritu či lídrov (Pophal 2016). Môže sa jednat' o umelcov, vedcov, spisovatel'ov, kuchárov, športovcov, l'udí v móde (Smutný 2018). Sú to osobnosti, ktoré dokážu vo vel'kej miere ovplyvnit' správanie a rozhodovanie zákazníkov. Dôležitý je práve vplyv (sila), ktorú získava jeden človek, resp. entita, a ktorá v iných l’ud'och vytvára určitú požadovanú reakciu (Brown, Fiorella 2013), z hl'adiska podniku je požadovanou reakciou nákup jeho produktu. Vel'ký rozvoj influencer marketingu súvisí najmä s rozmachom sociálnych sietí, ked’že práve na sociálnych siet’ach si vytvárajú svoj vlastný obsah (Visions 2017). Práve z daného dôvodu môžeme tvrdit', že predchodcom dnešného influencer marketingu bol tzv. sociálny marketing. V roku 1971 bol prvýkrát sociálny marketing definovaný ako aplikácia techník komerčného marketingu $\mathrm{v}$ procese plánovania, analyzovania, realizácie a hodnotenia programov navrhnutých, aby ovplyvňovali spontánne správanie ciel'ových skupín za účelom zlepšenia blahobytu jednotlivcov, ako aj celej spoločnosti (Hastings 2007).

Dnes sme svedkami toho, že podniky sa snažia vybrat' najvhodnejší a zároveň finančne najdostupnejší spôsob reklamy pre svoje produkty a služby. Influencer marketing je práve jedným z nich, pričom najčastejšie využíva nástroje ako blog, Facebook, Youtube, Instagram a pod. Potenciálnych zákazníkov okrem samotných produktov zaujíma hlavne názor a skúsenosti s produktom, tzv. recenzie. Podla Přikrylovej a Jahodovej (2010) podávanie informácií o skúsenostiach s výrobkami a službami tzv. word-of-mouth (WOM) prebiehalo medzi l'ud'mi už od nepamäti, najčastejšie formou tvárou v tvár. Kotler a kol. (2007) definujú WOM ako formu osobnej komunikácie, ktorá zahŕňa výmenu informácií o produkte/službe medzi ciel'ovými zákazníkmi, susedmi, priatel'mi, príbuznými alebo kolegami. V podstate vyvoláva dojem nezištnej pomoci alebo rady od priatel'a. Přikrylová a Jahodová (2010) rozlišujú dva typy WOM marketingu:

- spontánny - prirodzený a neformálny spôsob podávania informácií a skúseností s produktom/službou od jedného človeka $\mathrm{k}$ druhému. Bežné správanie spokojného zákazníka; 
- umelý - umelo vytvorený. Je výsledkom prieskumu a aktivít marketingového oddelenia spoločnosti s ciel'om podpory WOM medzi l'ud'mi.

Marketéri sa snažia nájst' dôvody a spôsoby, prečo a ako by mali l'udia šírit' pozitívne reakcie o ich produktoch/službách. Práve preto aj spoločnosti oslovujú influencerov čoraz častejšie. Popularita influencera sa meria aj počtom sledovatel'ov a odoberatel'ov na sociálnych siet'ach. Influencer marketing po odbornej stránke patrí $\mathrm{k}$ druhom tzv. virálneho marketingu pod WOM marketing alebo tzv. buzz marketing.

Reklama v súčasnosti zasiahla každé nové médium. Je preto prirodzené, že sa presunula aj na sociálne siete. V súčasnosti môžeme vidiet', že ak niečo propaguje verejne známa alebo obl'úbená osobnost', o to viac je reklama efektívna a uveritel'ná. Permanentný pokrok v internetových technológiách viedol k zásadným zmenám v komunikácii na B2C (Business to Consumer) trhoch. V minulosti pri tradičných technikách marketingu bol hlavný ciel' bezprostredný predaj. Predaj je stále podstatou podnikania, ale už nie je považovaný za jeho jedinú náplň. Podpora celého nákupného procesu sa stáva čoraz dôležitejšou. Autor Janouch (2011) tvrdí, že marketingová komunikácia v online priestore je viac rozsiahla, takže sa pochopitel'ne zameriava aj na viac ciel'ov.

Marketéri nevedia s určitost'ou odhadnút' reakcie spotrebitel'ov na isté marketingové t'ahy. Z tohto dôvodu je pri určení ciel'ovej skupiny, na ktorú je reklamná kampaň zameraná, nevyhnutné poznat' preferencie a požiadavky budúcich zákazníkov. Aj toto má s ciel'mi vel'mi úzky súvis, pretože jednotlivé odlišnosti v preferenciách delia a diverzifikujú skupiny tak, aby boli aj marketingové prostriedky rozdelené čo najviac efektívne. Stuchlík a Dvořáček (2000) delia marketingové ciele na tri hlavné skupiny a to informovat', presviedčat' a pripomínat'. Prvá skupina obsahuje aktivity ako oznámenie nového produktu/služby, ich prezentáciu, informácie o cene, popis funkcií, vysvetlenie používania s čím súvisí ciel’ znižovania nedôvery spotrebitel'ov a zároveň buduje image spoločnosti. V druhej skupine by sa spoločnost' mala zamerat' najmä na budovanie preferencií značky, povzbudenie zmeny značky, zmenit' spotrebitel'ovo vnímanie produktu/služby, presvedčit' ho, aby si vyžiadal d'alšie informácie a nakoniec výrobok kúpil. Tretia skupina zdôrazňuje, že predajom produktu/služby sa aktivity spoločnosti nekončia. Naopak, mala by sa pravidelne spotrebitel'om pripomínat', udržiavat' produkt/službu na popredných pozíciách v ich mysliach, ponúkat' produkty/služby aj mimo sezónu, aby spotrebitel' nezabudol, že ich vlastne potrebuje.

Dôležitým faktorom v rámci influencer marketingu je dôvera (Ehrenbergová 2018). Najväčšia sila influencerov spočíva $\mathrm{v}$ tom, že ich mnohí dokážu cez sociálne siete považovat' za priatel'ov. L'udia majú možnost' komunikovat', komentovat' ich fotografie, vyjadrit' ich názor či obdiv a čo je dôležité, môžu získat' aj spätnú reakciu. Podstatné je, aby sa influencer dokázal vymámit' z davu prostredníctvom svojej kreativity. Spoločnosti by si mali uvedomit', že influenceri majú cenné vedomosti o zákazníkoch práve na základe denného kontaktu s nimi. Vedia, ako sa publikum dá najlepšie oslovit'. Prostredníctvom seba dokážu predstavit' značku a stávajú sa jej dôveryhodnými vel'vyslancami. Influencer je sledovaný vtedy, ked' sa l'ud'om jeho tvorba páči a môžu mu dôverovat' (Juhász Szabó 2018 ).

\section{Analýza influencer marketingu na správanie spotrebitel'ov}

Ciel’om predloženého príspevku je na základe dotazníkového prieskumu zistit', či vybraný segment spotrebitel'ov považuje influencerov za dôležitý faktor, ktorý ovplyvňuje spotrebitel'ské správanie. Na hlavný ciel' nadväzujú dva čiastkové ciele. Prvým čiastkovým 
ciel'om je zistit' hlavné dôvody, prečo respondentky sledujú influencerov. Druhým čiastkovým ciel'om je zistit', či influencer marketing má vplyv na spotrebitel'ské správanie respondentiek a či si na základe odporúčania influencera v minulosti zakúpili určitý produkt. Na základe čiastkových ciel'ov sme formulovali dva predpoklady.

\section{Predpokladáme, že respondentky považujú za hlavný dôvod sledovania influencerov zdroj} nových informácií.

V tomto prípade sme pri stanovení predpokladu vychádzali z podstaty influencer marketingu a tým je najmä prezentácia nových produktov. Na základe uskutočneného výskumu na Fakulte sociálnych vied Karlovej Univerzity v roku 2018 vyplýva, že 46,6 \% opýtaných potvrdilo, že za hlavný motív sledovania influencerov považujú zdroj nových informácií. Preto sa domnievame, že influenceri patria $\mathrm{k}$ hodnotnému informačnému zdroju. $\mathrm{Z}$ toho môžeme dedukovat', že l'udia ich častokrát vyhl'adávajú práve za týmto účelom.

\section{Predpokladáme, že viac ako $50 \%$ respondentov si na základe odporúčania influencera} zakúpilo v minulosti určitý produkt.

Pri stanovení daného predpokladu sme vychádzali z uskutočneného prieskumu, ktorý vykonala agentúra Nielsen v roku 2015. Z výsledkov výskumu vyplynulo, že influencer marketing bol označený ako vel'mi dôveryhodný formát reklamy (Allen, 2015). Ďalším podkladom pri tvorbe daného predpokladu boli údaje získané z uskutočneného výskumu na Fakulte sociálnych vied Karlovej Univerzity v roku 2018. V otázke, či má názor influencera zásadný vplyv na rozhodovanie spotrebitel’a pri nákupnom procese, odpovedalo 79,2\% respondentov kladne (Skrytou reklamu na internetu pozná jen jedno dítě z deseti, zjistili výzkumníci z Univerzity Karlovy, 2018)

V nasledujúcej časti príspevku uvádzame výsledky dotazníkového prieskumu. Otázky v dotazníku boli formulované tak, aby bolo možné overit' stanovené predpoklady a naplnit' ciel' predloženého príspevku. Výskum sme sa rozhodli zamerat' na segment žien z niekol'kých dôvodov. CEO poradenskej firmy Ženský faktor za hlavný dôvod, prečo ženy tak nakupujú viac, považuje skutočnost', že ženy nenakupujú len pre seba, ale aj pre ostatných členov rodiny (Forbes 2013). Môžeme preto tvrdit', že predstavujú viaceré trhové segmenty $\mathrm{v}$ jednom. Takisto $\mathrm{z}$ pohl'adu online realizovaných nákupov vyplynulo, že ženy nakupujú ovel'a viac ako muži (Valentine, Powers 2013).

Vzhl'adom na analyzovanú problematiku príspevku považujeme dotazníkový prieskum za najvhodnejšiu techniku zberu dát, pretože umožňuje rýchle zozbieranie a spracovanie údajov a oslovenie relatívne vel'kej skupiny respondentov. Najväčšími nevýhodami dotazníkového prieskumu sú neochota respondentov spolupracovat', z čoho následne vyplýva nízka návratnost' odpovedí. Na tvorbu dotazníka sme použili nástroj Google Docs, pričom dotazník bol distribuovaný najmä elektronicky prostredníctvom sociálnych sietí v termíne od 4. marca 2019 do 18. marca 2019. Celkovo sa nám podarilo získat' 150 správne vyplnených dotazníkov. Vzhl’adom k tomu, že distribúcia dotazníka bola elektronická, nie je možné stanovit' jej mieru návratnosti, ked’že nevieme reálne posúdit' ku kol'kým respondentom sa dostal. Ked’že sa nám nepodarilo zabezpečit' reprezentatívnost' analyzovanej vzorky, čo považujeme za hlavné obmedzenie realizovaného prieskumu, výsledky dotazníka nemôžeme zovšeobecnit' na celý základný súbor (celkový segment žien na Slovensku). Dotazník pozostával z 29 otázok, ktoré boli rozdelené do troch častí (identifikačné otázky; zistenie všeobecných informácií o influencer marketingu; vplyv influencer marketingu na spotrebitel'ské správanie respondentiek). V predloženom príspevku prezentujeme iba odpovede na otázky, ktoré primárne súvisia so stanoveným ciel’om príspevku. Prvá čast' 
dotazníka bola zameraná na identifikačné údaje výskumnej vzorky, ktoré komplexne prezentuje tabul'ka 1 .

Tabul'ka 1: Identifikačné údaje výberového súboru

\begin{tabular}{|c|c|c|}
\hline Charakteristika & Absolútna početnost' & Relatívna početnost' \\
\hline \multicolumn{3}{|l|}{ Vek } \\
\hline do 18 rokov & 4 & $2,7 \%$ \\
\hline $19-25$ rokov & 113 & $75,3 \%$ \\
\hline $26-31$ rokov & 25 & $16,7 \%$ \\
\hline $32-40$ rokov & 7 & $4,7 \%$ \\
\hline 41 a viac & 1 & $0,7 \%$ \\
\hline \multicolumn{3}{|l|}{ Najvyššie dosiahnuté vzdelanie } \\
\hline základné & 5 & $3,3 \%$ \\
\hline stredoškolské bez maturity & 0 & $0 \%$ \\
\hline stredoškolské s maturitou & 68 & $45,3 \%$ \\
\hline vysokoškolské I. stupeň & 49 & $32,7 \%$ \\
\hline vysokoškolské II. stupeň & 26 & $17,3 \%$ \\
\hline vysokoškolské III. stupeň & 2 & $1,3 \%$ \\
\hline \multicolumn{3}{|l|}{ Súčasný stav } \\
\hline študentka & 96 & $64 \%$ \\
\hline zamestnaná & 46 & $30,7 \%$ \\
\hline nezamestnaná & 3 & $2 \%$ \\
\hline iné: napr. materská dovolenka & 5 & $3,5 \%$ \\
\hline \multicolumn{3}{|l|}{ Čistý mesačný príjem } \\
\hline do $250 €$ & 77 & $51,3 \%$ \\
\hline $251-500 €$ & 22 & $14,7 \%$ \\
\hline $501-750 €$ & 16 & $10,7 \%$ \\
\hline $751-1000 €$ & 19 & $12,7 \%$ \\
\hline viac ako $1000 €$ & 16 & $10,7 \%$ \\
\hline
\end{tabular}

Zdroj: Spracované na základe výsledkov dotazníkového prieskumu

Z výsledkov dotazníkového prieskumu vyplynulo, že podstatnú čast' analyzovanej vzorky 150 respondentiek tvoria ženy vo veku od 19 do 25 rokov $(75,3 \%)$. V otázke vzdelania má prevahu stredoškolské vzdelanie s maturitou (45,3\%). Z daného zistenia logicky vyplýva, že v súbore sú najviac zastúpené študentky (64 \%), čomu zodpovedá aj výška čistého mesačného príjmu do 250 euro $(51,3 \%)$. Influencer marketing vel'mi úzko súvisí so sociálnymi siet’ami, ktoré sa stali samozrejmost'ou pre generáciu tzv. mileniálov, ktorí sú zvyknutí žit' v digitálnej dobe, pričom majú úplne zmenené návyky v rámci spotrebitel'ského správania (Donnelly 2016). Vzhl'adom na to, nás zaujímala vo všeobecnosti najčastejšie používaná sociálna siet'. Za najviac používanú sociálnu siet' 67,30 \% opýtaných označilo Instagram. Na druhom mieste sa umiestnil Facebook, ktorý označilo 38 respondentiek (25,30 \%). Len $6 \%$ opýtaných ako najviac používanú sociálnu siet' označilo Youtube. V odpovedi iné 1,40\% respondentiek uviedlo sociálnu siet' Snapchat. Najviac opýtaných $(45,30 \%$, 68 respondentiek) trávi na sociálnych siet'ach denne 2-5 hodín.

Význam pojmu influencer pozná 83,30 \% opýtaných, $14 \%$ respondentiek sa s daným pojmom už stretlo, ale nevedia ho bližšie definovat'. 2,70 \% z opýtaných žien označilo možnost', že sa s pojmom influencer ešte nestretli a ani ho nepoznajú. Išlo o ženy vo veku 2631 rokov, ktoré majú ukončené vysokoškolské vzdelanie II. stupňa a momentálne sú zamestnané. V prípade pozitívnej odpovede respondentky uvádzali, čo si pod pojmom influencer predstavujú. Rozdiely v odpovediach boli len vel'mi nepatrné, pričom influencer 
bol najčastejšie označovaný ako ovplyvňovatel', čo aj korešponduje s jeho obsahovým vymedzením.

Kl'účovou otázkou v dotazníku bola otázka ohl'adom sledovania influencerov, ked’že jej výsledky rozdelili výberový súbor do dvoch skupín. Influencerov sleduje 121 respondentiek $(80,7 \%)$, z toho 54 pravidelne a 67 nepravidelne. Druhú skupinu respondentiek reprezentuje 19,3\% (29 opýtaných), ktoré influencerov nesledujú. Hlavnými dôvodmi nesledovania boli skutočnosti ako nezáujem o sociálne siete, ale najmä to, že názory influencera sú považované za vel'mi subjektívne.

V prípade, ak respondentky odpovedali, že influencerov sledujú, zaujímala nás klasifikácia ich počtu. Iba jedného influencera sleduje $5 \%$ opýtaných, dvoch až piatich influencerov sleduje 49,6 \% respondentiek a 20,7 \% označilo možnost' šest' až 10 influencerov. Až 24,8 \% z opýtaných žien sleduje viac ako desat' influencerov. Sociálne siete sú podstatnou a nevyhnutnou súčast'ou influencer marketingu a pre samotných influencerov predstavujú dôležitý nástroj. Respondentiek sme sa preto pýtali, na akých online platformách influencerov sledujú, pričom mohli uviest' viac ako jednu možnost'. Najväčšiu sledovanost' sme zaznamenali na sociálnej sieti Instagram $(92,6 \%)$, druhou v poradí bola možnost' Youtube (62 \%). 24,8 \% respondentiek označilo sociálnu siet' Facebook.

Pre samotného influencera je potrebné vediet', z akého dôvodu je jeho tvorba sledovaná. Práve preto d'alšia čast' dotazníka bola venovaná motívom a dôvodom. Respondentky mali uviest' tri najvýznamnejšie dôvody, prečo samotných influencerov sledujú. Nasledujúca tabul'ka zobrazuje výsledky danej otázky. Prvým najčastejšie označovaným motívom bol zaujímavý obsah a zdroj nových informácií, v percentuálnom vyjadrení ho označilo až 73,6 \% (89 respondentiek). Druhý v poradí $(67,8 \%$ ) bol označený motív zdroj inšpirácie. Ako tretí najdôležitejší faktor sledovania influencerov označilo 53,7 \% respondentiek faktor sympatie. Recenzie na produkty a služby ako dôležitý motív k sledovaniu činnosti influencera považuje 49,6 \% opýtaných. Ďalších 47,9 \% označilo motiváciu. V možnosti „iné“ sa objavila iba jedna odpoved', a to, že respondentky zaujímajú cestovatel'ské zážitky a skúsenosti. S týmto tvrdením sa stotožnilo 1,6\% (2 respondentky).

Tabul'ka 2: Motívy sledovania influencerov

\begin{tabular}{|l|c|c|}
\hline Motív & Absolútna početnost' & Relatívna početnost' \\
\hline Zaujímavý obsah a zdroj nových informácií & 89 & $73,6 \%$ \\
\hline Zdroj inšpirácie & 82 & $67,8 \%$ \\
\hline Sympatie & 65 & $53,7 \%$ \\
\hline Recenzie produktov & 60 & $49,6 \%$ \\
\hline Relax a zábava & 58 & $47,9 \%$ \\
\hline Motivácia & 26 & $21,5 \%$ \\
\hline Zážitky skúsenosti z cestovania & 2 & $1,6 \%$ \\
\hline
\end{tabular}

Zdroj: Spracované na základe výsledkov dotazníkového prieskumu

Z vyššie uvedenej tabul'ky môžeme dedukovat', že obsah tvorby influencerov je jeden z hlavných dôvodov, prečo ich l'udia radi sledujú. V nasledujúcej otázke sme sa preto zaujímali, aký konkrétny obsah považujú sledovatelia influencerov za najviac atraktívny. Jednotlivé odpovede sme zobrazili na obrázku 1 od najviac atraktívnych tém po tie najmenej atraktívne $\mathrm{v}$ závislosti od odpovedí respondentiek. Vzhl’adom k skutočnosti, že nami realizovaný prieskum sa týka žien, odpovede neboli vel'mi prekvapivé. Za najviac atraktívne témy považuje $61,2 \%$ žien módu, beauty \& make up. Následne za tým 44,6 \% respondentiek označilo fitness \& 
zdravý životný štýl. O niečo menej, ale stále zaujímavé, sú považované témy týkajúce sa cestovania. Túto možnost' označilo 43 \% žien. Vlogy sú populárne pre 33,1 \% opýtaných žien a prípravu jedál spoločne s gastronómiou za zaujímavé považuje $27,3 \%$ respondentiek. $\mathrm{Za}$ najmenej atraktívne témy respondentky považujú ekonomiku \& business $(5 \%)$. V poslednej možnosti „,iné“ boli uvedené iba tri oblasti, a to zábava, vzdelávanie a hudba.

Obrázok 1: Obsah tvorby influencerov

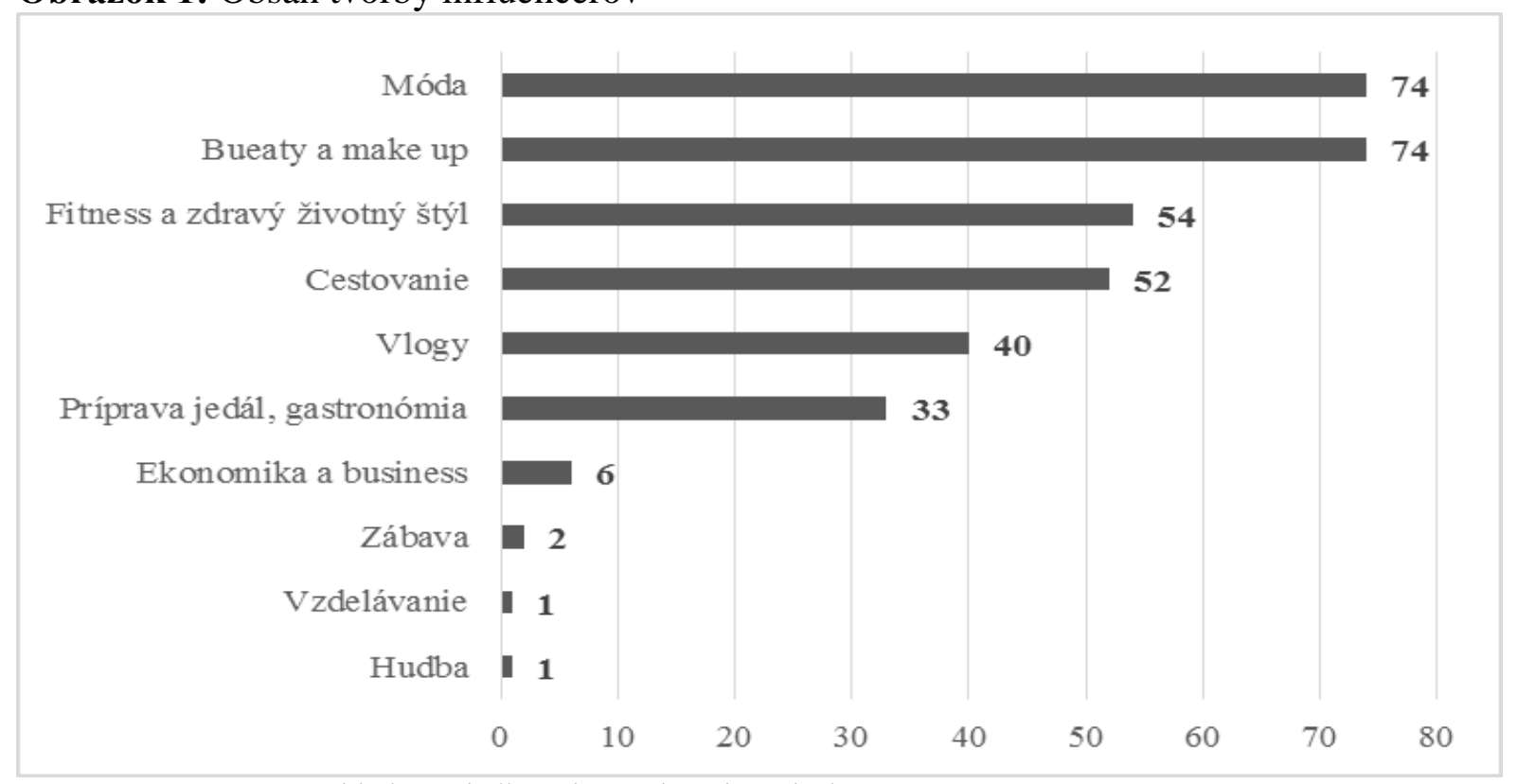

Zdroj: Spracované na základe výsledkov dotazníkového prieskumu

Následne sme sa zamerali na spotrebitel'ské správanie respondentiek v súvislosti $\mathrm{s}$ influencermi. Respondentky mali uviest', či si niekedy v minulosti kúpili produkt na základe odporúčania a recenzie influencera, pričom mali na výber jednu zo štyroch odpovedí. Najväčšie relatívne zastúpenie mala odpoved' ,áno, viackrát“, ktorú označilo 43,8 \% z nich. Jedná sa prevažne o študentky vo veku od 19-25 rokov. 24,8 \% opýtaných uviedlo, že si ešte nič nezakúpili, ale i napriek tomu recenzie influencerov sledujú. Produkt si iba jedenkrát zakúpilo $24 \%$ respondentiek. 7,4 \% opýtaných recenzie nijakým spôsobom neovplyvňujú a nemotivujú ku kúpe samotných produktov. V prípade pozitívnej odpovede na vyššie uvedenú otázku, sme sa d’alej zaujímali, aký konkrétny druh produktov, či služieb si respondentky zakúpili. Ukázalo sa, že až 79,5 \% (66 respondentiek) opýtaných žien si na základe recenzie od influencera kúpilo vybraný druh kozmetiky. Druhou najčastejšou odpoved'ou bolo oblečenie, ktorú uviedlo 34,9 \% respondentiek. 25,3 \% uviedlo, že na základe názoru influencera si kupuje jedlo, zatial' čo 16,9 \% uprednostňuje nákup fitness príslušenstva, kde spadá oblečenie a výživové doplnky, či aplikácie. Na názor influencera navštívilo reštauráciu alebo kaviareň 20,5 \% opýtaných a 4,8 \% žien na základe odporúčania influencera navštívilo kozmetický alebo kadernícky salón. Nákup dovolenky alebo zájazdu uskutočnilo $6 \%$ opýtaných. V možnosti „,iné“ sa s rovnakým relatívnym vyjadrením 1,2 \% objavili odpovede ako dron, kamera, knihy a rôzne ekologické produkty.

Dôležitá je takisto spokojnost' spotrebitel'ov so zakúpeným produktom. Z odpovedí vyplynulo, že 45,9 \% (39 respondentiek) opýtaných žien hodnotí svoju skúsenost' s takýmto nákupom pozitívne a prikláňa sa $\mathrm{k}$ odpovediam, že boli s nákupom určite, respektíve skôr spokojné. Iba 4,7 \% respondentiek sa vyjadrilo, že spokojné nie sú a v dotazníku označilo odpoved” „skôr nie“. Napokon 3,5 \% žien potvrdilo svoju absolútnu nespokojnost' s odpoved’ou „určite nie“. V tomto prípadne sa jedná o produkty kozmetického charakteru. 
V rámci dotazníkového prieskumu nás takisto zaujímalo, ktoré formy reklamy sú považované za najdôveryhodnejšie. Danú otázku sme konštruovali na základe už uskutočneného výskumu agentúry Nielsen v roku 2015 (Allen 2015). Výsledky odpovedí prezentuje nasledujúci obrázok.

Obrázok 2: Najdôveryhodnejšie reklamné formáty

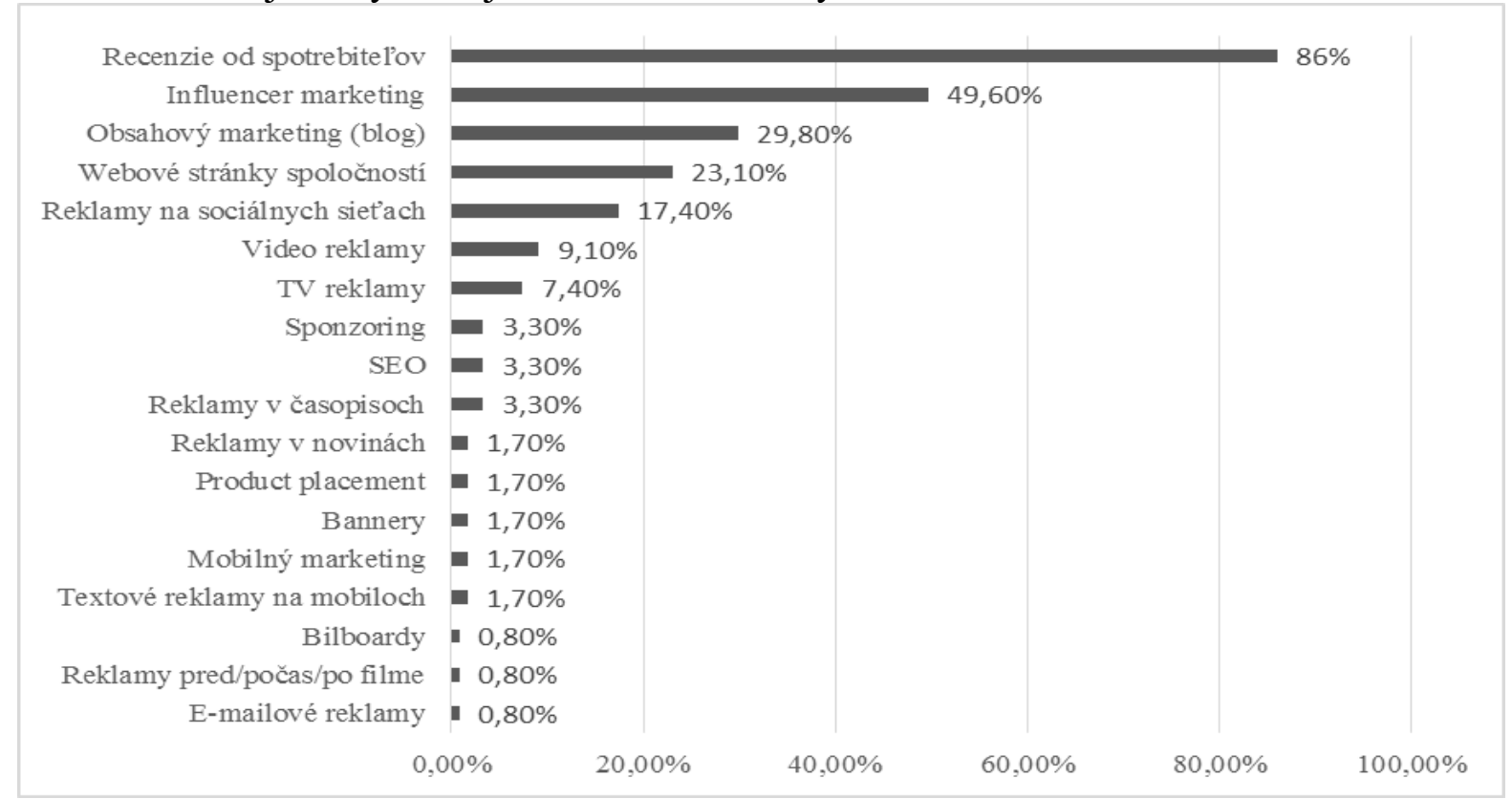

Zdroj: Spracované na základe výsledkov dotazníkového prieskumu

Hoci sa prvé tri odpovede líšia od seba pomerne významným percentuálnym bodom, v zásade sa jedná o vel'mi podobné typy reklám. Za najviac dôveryhodné reklamné formáty respondentky považujú recenzie od spotrebitel'ov (86\%), influencer marketing $(49,6 \%)$ a obsahový marketing $(29,8 \%)$. Webové stránky spoločností ako dôveryhodný zdroj reklamy označilo $23,1 \%$. Reklamy na sociálnych siet'ach sú vnímané pozitívne od 17,4 \% opýtaných, video reklamy od $9,1 \%$ a TV reklamy od 7,4\%. Ďalšie reklamné formáty získali rovnaký počet odpovedí. Sponzoring, SEO a reklamy v časopisoch ako dôveryhodné vníma 3,3\% opýtaných. Bannery, mobilný marketing a textové reklamy na mobilných telefónoch označilo $1,7 \%$ žien. Napokon za najmenej dôveryhodné reklamné formáty $0,8 \%$ respondentiek považuje billboardy, reklamy pred/počas/po filme a e-mailové reklamy.

Ako vyplynulo z predchádzajúcej otázky, recenzie sú medzi spotrebitel'mi vnímané ako pomerne dôveryhodné reklamné formáty. $Z$ tohto dôvodu sme sa v d'alšej otázke zaujímali, či sú aj zásadným motívom, prečo l’udia influencerov sledujú. Odpoved’ „áno“ označilo až $78,5 \%$ žien a odpoved” „nie“ $21,5 \%$ opýtaných. V prípade, že respondentky odpovedali kladne, pokračovali v nasledujúcej otázke, kde sme sa ich pýtali na konkrétne produkty a služby, ktorých recenzie sú podl'a nich atraktívne. Medzi najčastejšie odpovede patrili kozmetika, dekoratívna kozmetika a make up, oblečenie, fitness produkty, jedlo a nápoje, mobilné telefóny, čo je v súlade s informáciami, ktoré sme sa dozvedeli aj z vyššie uvedených otázok dotazníka.

\section{Záver}

Blogy, sociálne siete, internetové stránky a d'alšie moderné komunikačné nástroje sa stali súčast'ou denného života nielen spotrebitel'ov, ale aj jednotlivých podnikov (Musová, Poliačiková 2018), čo môžeme vidiet' práve v narastajúcej popularite influencer marketingu. 
Pre podniky ponúka možnost' spojenia sa so zákazníkom tým najoriginálnejším spôsobom. Ako uvádza Digital Information World Facebook, Youtube a Instagram sú v top trojici najoblúbenejších sociálnych sietí súčasnosti (6 things that all content marketers should know in 2019, 2019). Každá z týchto sociálnych sietí je svojim spôsobom odlišná a tým predstavuje iný význam v marketingovej komunikácii. Uvedené nástroje sa stali dôležitým nástrojom pre influencerov. Influenceri aktívne vystupujú na sociálnych siet'ach a sú schopní zaujat' vel'ké množstvo jedincov, ovplyvňovat' ich názory a správanie, či byt' vzorom a inšpiráciou. Vd'aka tomu sa ich aktivity stali súčast'ou reklamy a marketingu. Spoločnosti im ponúkajú spoluprácu, ked’že práve influenceri môžu jednoducho prezentovat' a ponúknut' ich produkty a zároveň ovplyvnit' spotrebitel'ské správanie tých, ktorí k nim majú pozitívny vzt'ah.

Z výsledkov dotazníkového prieskumu vyplynulo, že influencerov sledujú najmä ženy vo veku 19 až 25 rokov. Charakteristickou črtou danej generácie je technická zdatnost', preto konštatujeme, že daný výsledok korešponduje so záujmami respondentiek. V predloženom príspevku boli stanovené dva čiastkové ciele, na ktoré nadväzovali dva predpoklady. V prvom predpoklade sme vychádzali z toho, že respondentky za hlavný motív sledovania influencerov považujú zdroj nových informácií. Na základe vyššie uvedených výsledkov, môžeme tento predpoklad potvrdit'. 89 respondentiek $(73,6 \%)$ uviedlo, že influencerov sledujú najmä kvôli novým informáciám a zaujímavému obsahu ich tvorby. Dnešná doba vysokej informatizácie ovplyvnila spôsob, akým sa človek vie dostat' k informáciám. $Z$ vel'kej časti sú čerpané práve $\mathrm{z}$ internetu. Ked’že influenceri pôsobia hlavne na sociálnych siet'ach, aj oni sa stali vyhl'adávanými. Vel'ký počet sledovatel'ov, zdiel'aní a like-ov predstavuje pre l'udí sociálny dôkaz, prečo by mali názorom influencerov dôverovat', pričom dôvera a autentickost' sú považované za klúčové v influencer marketingu (Waller 2016). V druhom predpoklade sme sa zamerali na spotrebitel'ské správanie, pričom sme predpokladali, že aspoň $50 \%$ respondentiek si v minulosti na základe odporúčania influencera zakúpilo určitý produkt. Daný predpoklad sa potvrdil, ked’že až $67,8 \%$ respondentiek si už v minulosti zakúpilo produkt, ktorý influencer odporúčal (dokonca 43,8 \% uviedlo možnost' áno, viackrtá). Dané respondentky boli s produktom spokojné. Táto skutočnost' je príležitost'ou pre podnikatel'ské subjekty, ktoré sa primárne orientujú na segment mladých žien (napríklad podniky zaoberajúce sa módou). Dnes sa častokrát môžeme stretnút's tým, že módne kamenné, ale aj online obchody spolupracujú s módnymi influencerkami, resp. influencerkami zaoberajúcimi sa životným štýlom. Na takejto spolupráci fungujú napríklad nadnárodné podniky H\&M, GANT, C\&A, Canon, Nikon, SONY, Nike, Adidas, IKEA, Swarovski, TOPSHOP. Ďalšia možnost' spolupráce je prostredníctvom reklamných bannerov, ktoré podniky umiestnia na stránkach influencerov, s ktorými uzatvoria zmluvu o spolupráci.

V prípade, ak sa spoločnost' rozhodne oslovit' influencera na spoluprácu, je potrebné, aby sa zamerala aj na bližšie skúmanie jeho publika a oboznámila sa $\mathrm{s}$ jeho rôznorodost'ou, interakciou a jeho reakciou na propagácie, ktoré boli vykonané už v minulosti. Toto je možné na základe tzv. business profilu na sociálnej sieti Instagram, kde je možné zbierat' dáta o followeroch a generovat' celkovú analýzu automaticky. Dané zistenia sú možné aj pri konkrétnych príspevkoch. V praxi by si spoločnost' mohla tieto informácie vyžiadat' od influencera ešte pred uzavretím spolupráce, aby ich vedela porovnat' a následne zhodnotit', aký prínos môže v budúcnosti očakávat'. Takisto je dôležité, aby si spoločnosti, ale aj influenceri uvedomili, že pri uzavretí spolupráce si spoločnosti automaticky nekupujú pozitívnu recenziu a reklamu od influencera, ale malo by íst' o reálne a autentické posúdenie produktu, ktoré je zárukou kvality a dôvery. Práve tie následne obom stranám prinášajú pozitívne výsledky. 


\section{Literatúra}

[1] ALLEN, R., 2015. Which are the most effective advertising formats today? Smart Insights [online]. [vid. 15. 5. 2019 ]. Dostupné z: https://www.smartinsights.com/internet-advertising/most-effective-advertising-formats/

[2] BOKUNEWCZ, J. F. and J. SHULMAN, 2017. Influencer identification in Twitter networks of destination marketing organizations, Journal of Hospitality and Tourism Technology, 8(2), 205-2019. ISSN 1757-9880.

[3] BROWN, D. and S. FIORELLA, 2013. Influence marketing: how to create, manage, and measure brand influencers in social media marketing. Indianapolis, Indiana: Que. ISBN 9780789751041.

[4] DONNELY, K., 2016. Shopify [online]. [vid. 6. 6. 2019]. Dostupné z: http://www.shopify.com/blog/75614533-marketing-to-millennials-5-massive-trendsthatare-leading-the-way

[5] EHRENBERGOVÁ, N., 2018. Využití internetových influencerů jako nástroj marketingu online. [online]. [vid. 6. 6. 2019]. Bakalárska práca. Dostupné z: https://is.cuni.cz/webapps/zzp/detail/179721/

[6] Evision. 2017. Influencer. [online]. [vid. 12. 3. 2018]. Dostupné z: https://www.evisions.sk/stitek/influencer/

[7] HASTINGS, G., 2007. Social Marketing: Why should the Devil have all the best tunes?. Burlington, MA : Elsevier Science \& Technology. ISBN 978-0-7506-8350-0.

[8] JANOUCH, V., 2014. Internetový marketing. Brno: Computer Press. ISBN 978-80251-4311-7.

[9] JUHÁSZ SZABÓ, C., 2018. Čo robí influencera cenným? Trend.sk. [online]. [vid. 12. 3. 2019]. Dostupné Z: https://blog.etrend.sk/csilla-juhasz-szabo/co-robi-influenceracennym.html

[10] KÁDEKOVÁ, Z. a M. HOLIENČINOVÁ, 2018. Influencer marketing as a modern phenomenon creating a new frontier of virtual opportunities. Communication Today, 9(2), 90-104. ISSN 1338-130X.

[11] KOTLER, P, V. WONG, J. SAUNDERS a G. ARMSTRONG, 2007. Moderní marketing. 4 vydanie. Praha: Grada Publishing. ISBN 80-247-1545-7.

[12] LAGREE, P. a kol., 2019. Algorithms for Online Influencer Marketing. ACM TRANSACTIONS ON KNOWLEDGE DISCOVERY FROM DATA, 13(1), 1-30. ISSN 0736-721x.

[13] LEE, J. and I. B. HONG, 2016. Predicting positive user responses to social media advertising: The roles of emotional appeal, informativeness, and creativity. International Journal of Information Management [online]. 36(1), 360-373 [vid. 4. apríla 2018]. ISSN 0268-4012. Dostupné z: http://dx.dois.org/10.1016/j.ijinfomgt.2016.01.001.

[14] LEE, J. E. and B. WATKINS, 2016. YouTube vloggers' influence on consumer luxury brand perceptions and intentions. Journal of Business Research [online]. 69(1), 57535760 [vid. 4. mája 2018]. ISSN 0148-2963. Dostupné z: http://dx.doi.org/10.1016/j.busres.2016.04.171

[15] MINÁROVÁ, M., 2017. Pracovné prostredie - faktor kreativity a zvyšovania konkurencieschopnosti podnikov na Slovensku. In: Vplyv inovativnych marketingových koncepcii na správanie vybraných trhových subjektov na Slovensku. Zborník vedeckých 
prác z projektu VEGA 1/0802/16. Banská Bystrica: Belianum. Vydavatel'stvo UMB v BB, Ekonomická fakulta, s. 116-126. ISBN 978-80-557-1346-5.

[16] MUSOVÁ, Z. and E. POLIAČIKOVÁ, 2018. Consumers' Perception of Digital Marketing Tools. In: Marketing Identity 2018. Digital Mirrors - part I. Trnava: Faculty of Mass Media Communication, University of Ss. Cyril and Methodius in Trnava, s. 430440. ISBN 978-80-8105-984-1.

[17] POPHAL, L., 2016. Influencer marketing: Turning taste makers into your best salespeople. EContent [online]. 39(7), 18-22 [vid. 6.6.2019]. ISSN 15252531. Dostupné z: $\quad$ http://www.econtentmag.com/Articles/Editorial/Feature/Influencer-MarketingTurning-Taste-Makers-Into-Your-Best-Salespeople-113151.htm

[18] PǨIKRYLOVÁ, J. a H. JAHODOVÁ, 2010. Moderní marketingová komunikace. Praha: Grada Publishing, a.s. ISBN 978-80-247-3622-8.

[19] Skrytou reklamu na internetu pozná jen jedno dítě z deseti, zjistili výzkumníci z Univerzity Karlovy. 2018. Fakulta socálnych věd. Univerzita Karlova. [online]. [vid. 6. 6. 2019]. Dostupné z: https://fsv.cuni.cz/skrytou-reklamu-na-internetu-pozna-jen-jednodite-z-deseti-zjistili-vyzkumnici-z-univerzity-karlovy

[20] SMUTNÝ, T., 2018. Influenceri - nové celebrity a ich význam v marketingu. In: Študentská vedecká aktivita 2018. Zborník prác študentov. Banská Bystrica: Ekonomická fakulta UMB v Banskej Bystrici. ISBN 978-80-557-1401-1.

[21] STUCHLÍK, P. a M. DVOŘÁČEK, 2000. Marketing na Internetu. Praha: Grada Publishing. ISBN 80-7169-957-8.

[22] The real reason women shop more than men. 2013. Forbes [online]. [vid. 14. 4. 2019]. Dostupné z: https://www.forbes.com/sites/bridgetbrennan/2013/03/06/the-real-reasonwomen-shop-more-than-men/\#5791885574b9

[23] VALENTINE, D. B. and T. L. POWERS, 2013. Generation Y values and lifestyle segments. Journal of Consumer Marketing, 30(7), 597-606. ISSN 0736-3761.

[24] 6 things that all content marketers should know in 2019 [online]. [vid. 6. 6. 2019]. Dostupné z: https://www.digitalinformationworld.com/2019/05/2019-b2b-and-b2ccontent-marketing-statistics-infographic.html 